\title{
Local Responses to Marine Conservation in Zanzibar, Tanzania
}

\author{
Arielle Levine \\ Dept. of Environmental Science, Policy, and Management \\ University of California, Berkeley \\ 135 Giannini Hall \\ Berkeley, CA 94720 \\ (510) 643-3594 \\ alevine@nature.berkeley.edu
}

\begin{abstract}
While terrestrial parks and reserves have existed in Tanzania since colonial times, marine protected areas are a much newer endeavor in natural resource conservation. As the importance of marine conservation came to the international forefront in the 1990s, Tanzania experienced a rapid establishment and expansion of marine parks and protected areas. These efforts were indeed crucial to protecting the country's marine resource base, but they also had significant implications for the lives and fishing patterns of local artisanal fishermen. Terrestrial protected areas in Tanzania have historically been riddled with conflict and local contestation, bringing about numerous debates on the best ways to involve rural residents in conservation planning efforts to establish new "community-based conservation" programs. However, because marine protected areas do not have the same history as terrestrial conservation in Tanzania, marine conservation programs present a new opportunity to pilot innovative techniques to involve local communities in protecting and managing their natural resources. The islands of Zanzibar are home to four community-oriented marine protected areas, each of which is sponsored by an external agency, and each of which involves some form of local community component. However, a number of issues arise when working at the community level, requiring nuanced attention to a variety of local factors. The Menai Bay program in southern Zanzibar provides an excellent example of the complexity of factors involved, which can result in dramatically different village-level responses to a single program. These factors include, but are not limited to, differences in geography and infrastructure, the potential for tourism development and alternative sources of income, pre-existing community structures within each village, and the relationship of conservation program managers to the Zanzibari government. While these factors are complex and difficult to predict, it is essential that conservation programs take them into account when trying to establish community-based marine conservation programs that will be sustainable in the long-term.
\end{abstract}




\section{Introduction}

Tanzania is internationally renowned for its parks and protected areas. With over $25 \%$ of its land surface set aside in parks, protected areas, and wildlife reserves, the country has placed a high priority on safeguarding the country's valuable wildlife and land resources (Leader-Williams et. al. 1996). Many of these areas were established during the colonial period, and the number of national Parks in Tanzania rapidly expanded after the country gained independence in 1961. Parks, protected areas, and game reserves provide a significant source of revenue for the country through international tourism, as well as through funding from international conservation and development agencies

While terrestrial conservation in Tanzania dates back to colonial times, marine conservation has only recently come into the spotlight. The Tanzanian government began to designate a few small marine reserves off the coast of Dar es Salaam in 1975. However, these were mainly 'paper parks' with little enforcement of effect. In the 1990s, marine conservation began in earnest with the ratification of the Marine Parks and Reserves Act in 1994 (Spaulding et al. 2001). (see table 1) Since then, marine protected areas have expanded rapidly.

Table 1: Marine Protected Areas in Tanzania

\begin{tabular}{|l|l|c|c|}
\hline Site name & Designation & IUCN category & Year designated \\
\hline Bongoyo Island & Marine Reserve & II & 1975 \\
\hline Fungu Yasini & Marine Reserve & II & 1975 \\
\hline Mbudya & Marine Reserve & II & 1975 \\
\hline Pangavini & Marine Reserve & II & 1975 \\
\hline Maziwi Island & Marine Reserve & II & 1981 \\
\hline Chumbe Island Coral Park* & Marine Sanctuary & II & 1994 \\
\hline Mafia Island & Marine Park & VI & 1995 \\
\hline Menai Bay* & Conservation Area & VI & 1997 \\
\hline Mnemba* & Conservation Area & VI & 1997 \\
\hline Misali Island* & Conservation Area & VI & 1998 \\
\hline Mnazi Bay - Rovuma Estuary & Marine Park & VI & 2000 \\
\hline
\end{tabular}

*Protected areas in Zanzibar

(Source: Modified from Spaulding et. al. 2001)

At the same time that this new focus was beginning on marine conservation in Tanzania and internationally, conservation and protected area management in general was undergoing a dramatic revolution in thinking. Exclusionary models of parks and protected areas had resulted in years of rural hardship and conflict with local communities (see for example Neumann 1998), and conservation organizations began formulating more participatory models of involving local communities in "community-based conservation" and "community-based natural resource management" programs in Tanzania and other developing countries around the world (see Brandon \& Wells, 1992; Murphree 1993; Gibson \& Marks, 1995; Leader-Williams et. al., 1996; Brosius et. al 1998; Newmark \& Hough, 2000). Conservation and development organizations began acknowledging the importance of obtaining community support and returning benefits to local people in order guarantee the long-term sustainability of their programs. Community-based conservation was heralded as the way of the future for natural resource management in developing countries, and organizations ranging from government agencies to NGOs, international development institutions, and private tourism operators gradually began to incorporate local communities into their conservation agendas. 
By the end of the 1990s, it was difficult to find a conservation area in Tanzania that did not have a community component sponsored by an associated donor agency. Tanzania National Parks (TANAPA) established a Community Conservation Service to work with communities outside of national parks, supported by the African Wildlife Foundation (AWF) and World Wide Fund for Nature (WWF), the two primary wildlife NGOs in the country. AWF received considerable funding from USAID in the late 1980s and 1990s to establish community-based conservation programs (AWF 2000), and community components were becoming an increasingly important focus of WWF's programs (Dudley and Stolton 2003). CARE International had established Integrated Conservation-Development Programs (ICDPs) around many of the country's protected Forests. Increasingly, some tourist operators were also beginning to incorporate community benefit programs with neighboring communities around their primary safari sites (Kangwana and Mako 1998).

Because marine protection was initiated more recently and during the same time that this shift in thinking towards community-based methods of conservation was underway, marine programs do not have the same extensive history of conflict as land-based conservation programs in Tanzania. Given this context, marine protected areas therefore provide a tremendous opportunity to pilot innovative conservation initiatives in collaboration with local community and user groups. Many experimental techniques are currently underway to work with local communities around marine protected areas, often incorporating methods used in land-based conservation strategies.

However, the issues involved in terrestrial community-based conservation initiatives face new twists when applied to the marine environment. Most of TANAPA's community programs have been focused on working with Tanzania's sizeable rural agricultural and pastoral populations. Marine conservation faces additional challenges in the diffuse nature of fishermen user groups that are often hard to define as traditional "communities," in the highly fugitive nature of fisheries resources, and in the fact that marine borders that are extremely difficult to demarcate and enforce. While terrestrial community-based conservation tends to focus on working with neighboring villages, fisheries resources are often used by people who come from great distances and neighboring "resident" communities may not exist. In the cases where communities do live adjacent to the protected area, the involvement of only these nearby communities may overlook the effects on and importance of other key resource users. This is problem comes up whether the program is trying empower local user-groups as resource managers or simply distributing benefits to local populations to compensate for lost access to resources.

\section{Marine Conservation in Zanzibar}

In light of the above challenges, establishing community-based marine conservation programs is a daunting, but important, undertaking. A number of these kinds of programs have been established in Tanzania over the past decade, four of which are located in the islands of Zanzibar. (fig. 1) Zanzibar is a separate state within the United Republic of Tanzania, composed of two main islands, Unguja and Pemba, and a number of smaller fringing islets. Fishing is an extremely important livelihood activity for the majority of Zanzibar's rural coastal populations, and this together with small-scale agriculture, coconut and spice growing, and more recently tourism make up the bulk of Zanzibar's economy. Although part of the Republic of Tanzania, 
the government of Zanzibar maintains its own departments and ministries for internal matters, and natural resource protection falls within the jurisdiction of the Zanzibari government.

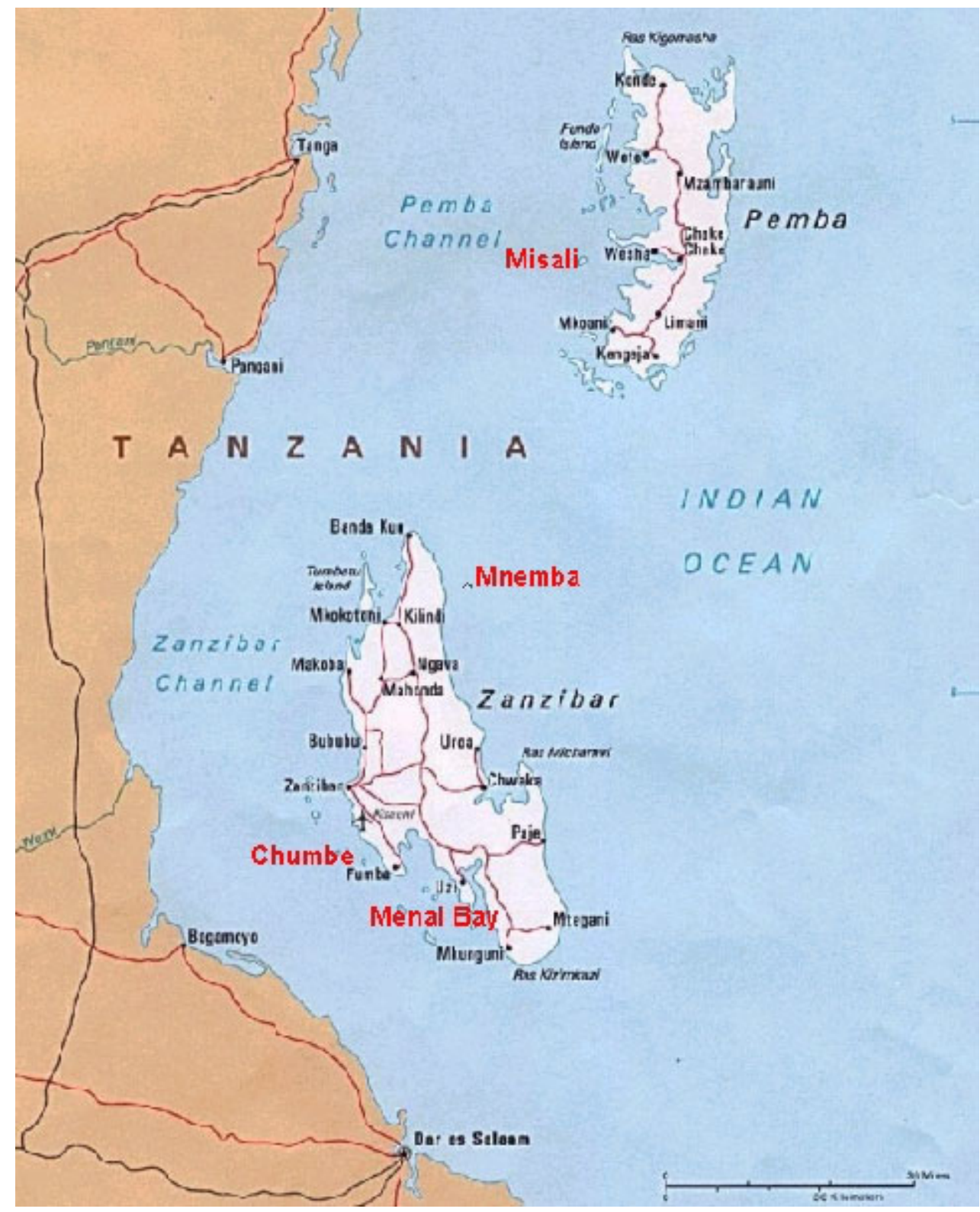

Fig. 1

(Source: Adapted from U.S. Central Intelligence Agency, 1977)

Each of Zanzibar's four marine protected areas involves some form of community component. This is done primarily through involving local communities in the management of these areas and/or providing nearby communities with benefits derived from conservation in the area. Two of the programs in Zanzibar are sponsored by international non-governmental organizations (NGOs), and the other two are managed by private sector, eco-tour operators. (table 2) 
Table 2: Marine Conservation Areas in Zanzibar

\begin{tabular}{|l|l|l|l|}
\hline $\begin{array}{l}\text { Conservation } \\
\text { Program }\end{array}$ & $\begin{array}{l}\text { Program } \\
\text { Type }\end{array}$ & $\begin{array}{l}\text { Implementing } \\
\text { Organizations }\end{array}$ & $\begin{array}{l}\text { Location and Involved } \\
\text { Communities }\end{array}$ \\
\hline $\begin{array}{l}\text { Marsali Island } \\
\text { Area }\end{array}$ & $\begin{array}{l}\text { Non- } \\
\text { governmental } \\
\text { organization } \\
\text { (NGO) }\end{array}$ & $\begin{array}{l}\text { CARE International } \\
\text { Government of Zanzibar - } \\
\text { Department of Commercial } \\
\text { Crops, Fruits, and Forestry } \\
\text { (DCCFF) }\end{array}$ & $\begin{array}{l}\text { Works actively with 12 user } \\
\text { communities (shehias) around Pemba; } \\
\text { involves 34 shehias in fishermen's } \\
\text { association (MICA) }\end{array}$ \\
\hline $\begin{array}{l}\text { Menai Bay } \\
\text { Area }\end{array}$ & $\begin{array}{l}\text { Nonservation } \\
\text { governmental } \\
\text { Association (MICA) }\end{array}$ & $\begin{array}{l}\text { World Wide Fund for } \\
\text { Nature (WWF) }\end{array}$ & Menai Bay, Southern part of Zanzibar \\
(NGO) & $\begin{array}{l}\text { Government of Zanzibar - } \\
\text { Department of Fisheries }\end{array}$ & $\begin{array}{l}\text { Involves 17 user villages in the Menai } \\
\text { Bay area }\end{array}$ \\
\hline $\begin{array}{l}\text { Mnemba } \\
\text { Island }\end{array}$ & $\begin{array}{l}\text { Private } \\
\text { Sector }\end{array}$ & $\begin{array}{l}\text { Conservation Corporation } \\
\text { Africa }\end{array}$ & Mnemba Atoll, NE of Zanzibar \\
& $\begin{array}{l}\text { Government of Zanzibar - } \\
\text { Department of Fisheries }\end{array}$ & $\begin{array}{l}\text { Involves 4 nearby user communities } \\
\text { (shehias) }\end{array}$ \\
\hline $\begin{array}{l}\text { Chumbe } \\
\text { Island }\end{array}$ & $\begin{array}{l}\text { Private } \\
\text { Sector }\end{array}$ & $\begin{array}{l}\text { Ltd. } \\
\text { Government of Zanzibar - } \\
\text { Department of Fisheries }\end{array}$ & $\begin{array}{l}\text { Chumbe Island, West of Zanzibar } \\
\text { Zanzibar teachers and schoolchildren }\end{array}$ \\
\hline
\end{tabular}

An interesting feature of marine conservation programs in Zanzibar is that all were initiated through the efforts of external organizations, and each are in some way supported and managed, in part or in full, by outside agencies other than the government. Indeed, the divisions of government that would normally be responsible for managing protected areas do not have the funding or resources to manage these protected areas themselves. While many government programs were supported heavily in the past by international development funding, during the 1980s the international donor community shifted its funding priorities away from providing direct assistance to the state. Now donor institutions emphasize decentralization or privatization of state functions, preferring to work through what are often referred to as "civil society" organizations, which are deemed to be more efficient and representative of society, or through private sector operators, which are also seen as more efficient and flexible than the bureaucratic government structures. In essence, this means that the majority of donor support to Tanzania is now distributed through intermediary organizations such as NGOs (often seen as institutional representatives of civil society), or it is used to encourage private sector initiatives, with very little going directly to the state (Gibbon 1995; Levine 2002). On top of this general trend, the political corruption and human rights violations associated with Zanzibar's elections in 1995 and 2000 (Human Rights Watch 2002) caused the rapid withdrawal of many of the state's remaining sources of international development funding, leaving the Zanzibar government even more strapped for resources (see Bigg 1996). The private sector and international NGOs were two of the few resources left for the Zanzibar government to turn to for support. 
Addressing this severe lack of funding and government capacity, Zanzibar's Environmental Management for Sustainable Development Act of 1996 specifically provides that the National Protected Area Board of Zanzibar can delegate its authority to institutions or individuals not employed by the government, stating that the Board "may delegate in writing any of the National Protected Areas Board's powers except its power to recommend national protected area status to the Minister responsible for the national protected areas system.” (Government of Zanzibar 1997). This appointment may be made to "any person qualified to exercise those powers," thus opening the potential for NGOs, the private sector, and local communities to become involved in protected area management. While the government still retains authority over reserve designation and delegating reserve management powers, a good deal of the responsibility for managing and funding Zanzibar's marine protected areas currently lies in the hands of outside agencies.

Because of the current priority of involving local communities in conservation programs, each of the institutions managing these protected areas (be it private sector or NGO), has incorporated a community component into its management plans. However, it is nearly impossible for these external organizations to engage directly with local communities without working through preexisting structures established by the Zanzibari government. Thus, while the Environmental Management for Sustainable Development Act writes the Zanzibari state out of the management of many protected areas, external managing institutions are still required to work through the state in order to reach local communities. This creates a rather convoluted relationship between protected area managers, the government, and local communities, which is not necessarily conducive to building strong and sustainable conservation programs (Levine forthcoming 2004).

\section{Communities and Conservation: NGOs and Private Sector Programs}

The policies set forth under Zanzibar's Protected Area Management Plan have opened up an opportunity for the involvement of a variety of institutions in marine protected area management and have resulted in a wide range of conservation programs and methods in a relatively small area. This has also created a natural experiment for assessing the outcome of different management styles, particularly the difference between private sector and NGO techniques for conservation and community involvement. As might be expected, village members' views of and reactions to conservation area programs vary greatly between each different program. However, their responses also vary just as dramatically between villages within an individual programs. A single management institution may experience a positive response from a community in one village, while members of a different village may react strongly against the same program.

To assess local responses to the different types of conservation programs, in-depth questionnairebased interviews were conducted in 2002 with over 500 fishermen in twenty-five shehias ${ }^{1}$ involved in each of the four marine conservation programs in Zanzibar. Focus group discussions were also conducted with groups of fishermen in each village. Preliminary results from this research show that while there is no dramatic difference between overall project satisfaction in villages involved in NGO vs. private sector programs, there is a striking difference in the

\footnotetext{
${ }^{1}$ Shehia refers to the administrative district just above the village level. Some shehias involve only one village, while others incorporate a few villages located in close proximity to each other.
} 
extremity of the fishermen's reactions. Fishermen located in villages associated with private sector programs tend to be passively accepting in their attitude toward the programs. They may be somewhat disappointed to lose access to a fishing area, but are perhaps pleased to be receiving benefits from program funding in their villages. On the other hand, fishermen located in villages sponsored by NGOs often exhibit a much more extreme response. When the NGO programs are meeting community expectations, community members feel highly involved in and enthusiastic about the conservation initiatives. Conversely, if the program fails to live up to its promises, local community members may exhibit outrage and threaten to rebel against the program itself.

This dramatic difference in community-level responses appears surprising until one examines the different techniques used by NGO vs. private sector programs in implementing communitybased conservation. NGOs tend to focus much more on building community-level structures, actively trying to involve fishermen in conservation and/or management. Fishermen are encouraged to form village conservation committees and may participate in patrols or become involved in deciding management issues. This creates an overall sense of engagement and community-level investment in the conservation programs. Private sector programs, on the other hand, operate more as socially responsible businesses. The hotels incorporate a conservation component to their operations and try to provide benefits to local community members. Ecotourism is a profitable niche market, and community and environmental programs provide positive publicity for the hotels, as well as help to ensure good local relations. Local communities are not actively involved in management, but are passive recipients of some of the hotels’ profits derived from tourism.

While a highly engaged community is much more likely to feel invested in a conservation program, this in itself cannot guarantee a positive community response. The overall outcome of a community-based conservation program at the local level depends on numerous other factors beyond the type of implementing institution, or even the techniques used to carry out the program. These factors are often complex and unpredictable, and can be either internal or external to the village or program itself. Additionally, programs are not static in time, but change continuously in response to a changing program environment. In spite of the complex issues involved in these programs, it is important to try to understand and adapt to these issues in program planning and implementation in order to address current problems and make programs more sustainable for the future.

\section{The Menai Bay Conservation Area Program}

Among the marine conservation programs in Zanzibar, the Menai Bay Conservation Area provides an excellent example of the potential for extreme variation in local response within a single program. Sponsored by the World Wide Fund for Nature (WWF), the Menai program is located in southern Zanzibar, encompassing an area of about $470 \mathrm{~km}^{2}$ (see fig. 2) and currently works with 19 villages in the Menai Bay area. The program was initiated in 1994, and the region was officially gazetted as a protected area in 1997. While WWF has funded most of the program, it has collaborated with the Department of Fisheries of the Zanzibar government to work with local villages and has received financial assistance from USAID, the British government, and other sources to finance certain aspects of the program. 


\section{Zanzibar: Menai Bay Marine Conservation Area}

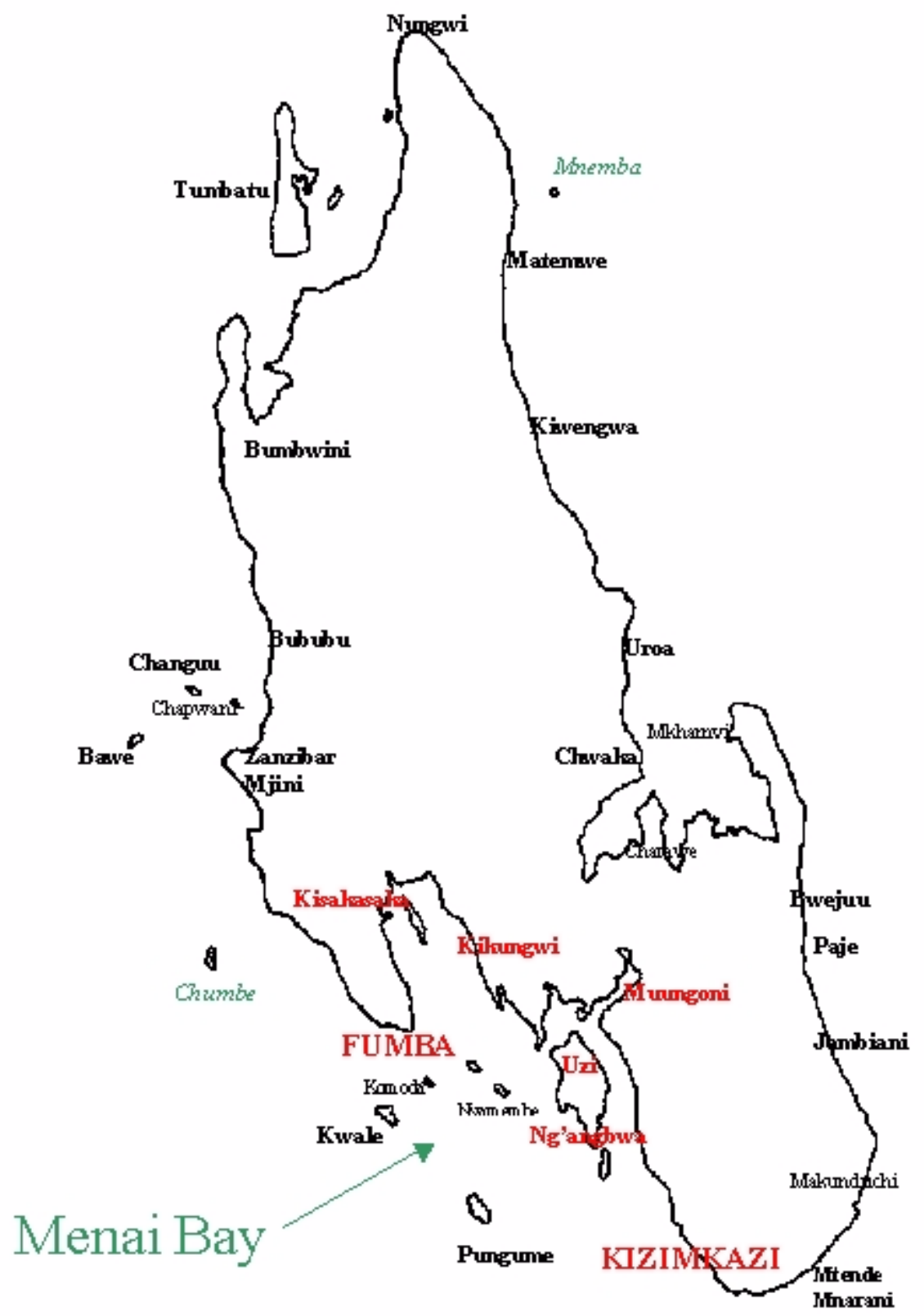

Fig. 2

The primary aims of the Menai Bay program are to sustain the biological resources of Menai Bay through the establishment of a multi-user marine conservation area, ensure local participation in conservation and monitoring of the protected area, and to increase public awareness and education. The project also hopes to increase local capacity for sustaining conservation activities, as well as to provide sources of revenue to improve local livelihoods and to make the project self-supporting in the long-term (Ngaga et. al. 1999). To address these goals, each of the villages involved in the program has organized village conservation committees (VCCs) that provide a structure through which the program contacts and works with each village. The VCCs 
are also intended as a way of organizing village members to focus on issues of environmental protection such as mangrove replanting and reduction of dynamite fishing and illegal nets (Menai Bay Conservation Project 2000).

To address the problem of destructive fishing in the area, the Menai program has established a system of local patrolling where fishermen from participating villages take on their boats to report incidences of illegal fishing. Five radios were distributed amongst the villages, and two patrol boats are stationed in Kizimkazi Dimbani on the east end of the Bay. The patrol sometimes works together with the local coast-guard (KMKM) to intercept illegal fishermen; between 1997 and 1999, 12 cases of illegal fishing involving 167 fishermen were brought to court (Ngaga et. al. 1999). Although fishermen continue to complain that fishermen who are prosecuted are rarely punished in any substantial way (only 40 fishermen involved in the above cases were actually fined), most villagers have reported a significant reduction in dynamite fishing in the Bay since the program was initiated, particularly in the area around Pungume island in the South.

WWF is also working to promote alternative sources of income in the Menai Bay villages. Tourism is actively promoted in some of the involved villages to bring in additional income to improve the livelihoods of local people, as well as to provide revenue to support conservation activities and program expenses in the Bay. Some villages have also received assistance and training for alternative income strategies such as bee-keeping, tree nurseries, and improved charcoal making techniques.

\section{Village-level Outcomes in Menai Bay}

The Menai Bay program has used a fairly consistent model for conservation and community involvement when working with each of the involved communities. The VCC structure is virtually identical in each village, and the program has used similar methods for promoting conservation and alternative livelihoods (such as radio patrols and forming women's bee-keeping groups to work in mangrove areas). However, although the model for implementing conservation programs is similar across villages, the outcomes at the village level have not been as consistent as the stated approach. This has resulted in highly divergent responses from community members within different villages, as well as high variation in village participation in and support of the programs.

The Menai case-study involved intensive interviews and focus group discussions with fishermen in seven of the program villages situated across Menai Bay. While every village is unique, and thus different outcomes would be expected in each area, the variation in community responses from different villages within Menai Bay is extreme, with program satisfaction generally higher on the eastern end of the Bay than in the West. These differences are due to a number of factors, both internal and external to the villages. These factors include, but are not limited to, differences in the infrastructure and geography of an area, local differences in history and fishing methods, the presence of illegal fishing in the area (from either village members or outsiders), village members' access to alternative means of income, the degree of the community's dependence on fishing for their livelihood, and variations in the previously existing social structures and history of local conservation efforts found within each village. 
Two villages in particular exemplify this extremity of variation in responses: Kizimkazi Dimbani (located on the far eastern end of the Bay) and Fumba (on the far western peninsula of the Bay). Fishermen in Kizimkazi Dimbani are generally highly enthusiastic about the project, believing that it has helped their village tremendously, both through the reduction of illegal fishing, as well as through an improvement in their overall livelihoods. The village of Fumba, on the other end of the Bay, is much less enthusiastic about the project (fig. 3). While fishermen who are members of the VCC in Fumba seem to have a slightly more positive opinion of the program (a trend seen in all villages), generally Fumba fishermen are pessimistic about the program's ability to reduce illegal fishing in their area or to improve their overall situation (fig. 4). Many of the differences between these two villages in local responses to the program can be explained by the aforementioned factors, a subset of which are discussed below.


$$
\begin{aligned}
& \square \text { Enthusiastic about project } \\
& \square \text { Dislike project } \\
& \square \text { Mixed feelings about project }
\end{aligned}
$$

Fig. 3

\section{Geography and infrastructure}

Differences in infrastructure are perhaps the most obvious factors accounting for these divergent responses. Although Kizimkazi Dimbani is much farther from the project headquarters in town, a well-maintained paved road runs all the way to the village. Fumba is physically much closer to town, but the road to reach the village is in poor condition, and driving to Fumba actually takes longer than the trip to Kizimkazi Dimbani. A common complaint among many fishermen is that program officials don't come to their villages, and indeed program officers rarely make the grueling trip to Fumba. The smooth road to Kizimkazi Dimbani, however, also allows project officials to stop at other project villages en route, making a trip to this village both comfortable and convenient. Not surprisingly, program officers are much more inclined to visit Kizimkazi Dimbani than Fumba, and the village gets much more attention from the program.

Additionally, Kizimkazi Dimbani serves as the base for the program's two patrol boats and radio headquarters. One of these two boats contains two powerful outboard engines that theoretically enable the patrol team to intercept almost any illegal fishing boat that enters the Bay. However, these impressive engines also use a considerable amount of fuel, and the limited project funds are 
often inadequate to support the cost of fuelling these boats. Project officers frequently lack sufficient fuel to take the boats on patrol or to intercept illegal fishermen outside the immediate area of Kizimkazi Dimbani.

As Fumba is located on the opposite end of the Bay from Kizimkazi Dimbani, the patrol boat is rarely able to arrive there in a timely manner in response to illegal fishing, even if adequate fuel resources are on hand to make the trip across the Bay. Both Fumba and Kizimkazi experience a number of outsiders fishing in their area. However, Fumba is located closer to the mainland and to town, meaning that the perceived threat of outside fishermen using illegal methods is greater. (fig. 4) The presence of the patrol boats in Kizimkazi Dimbani serves as a deterrent to illegal fishing in that area, while fishermen in Fumba do not generally believe that program has helped to significantly reduce illegal fishing.

\section{Threat of Illegal Fishing}

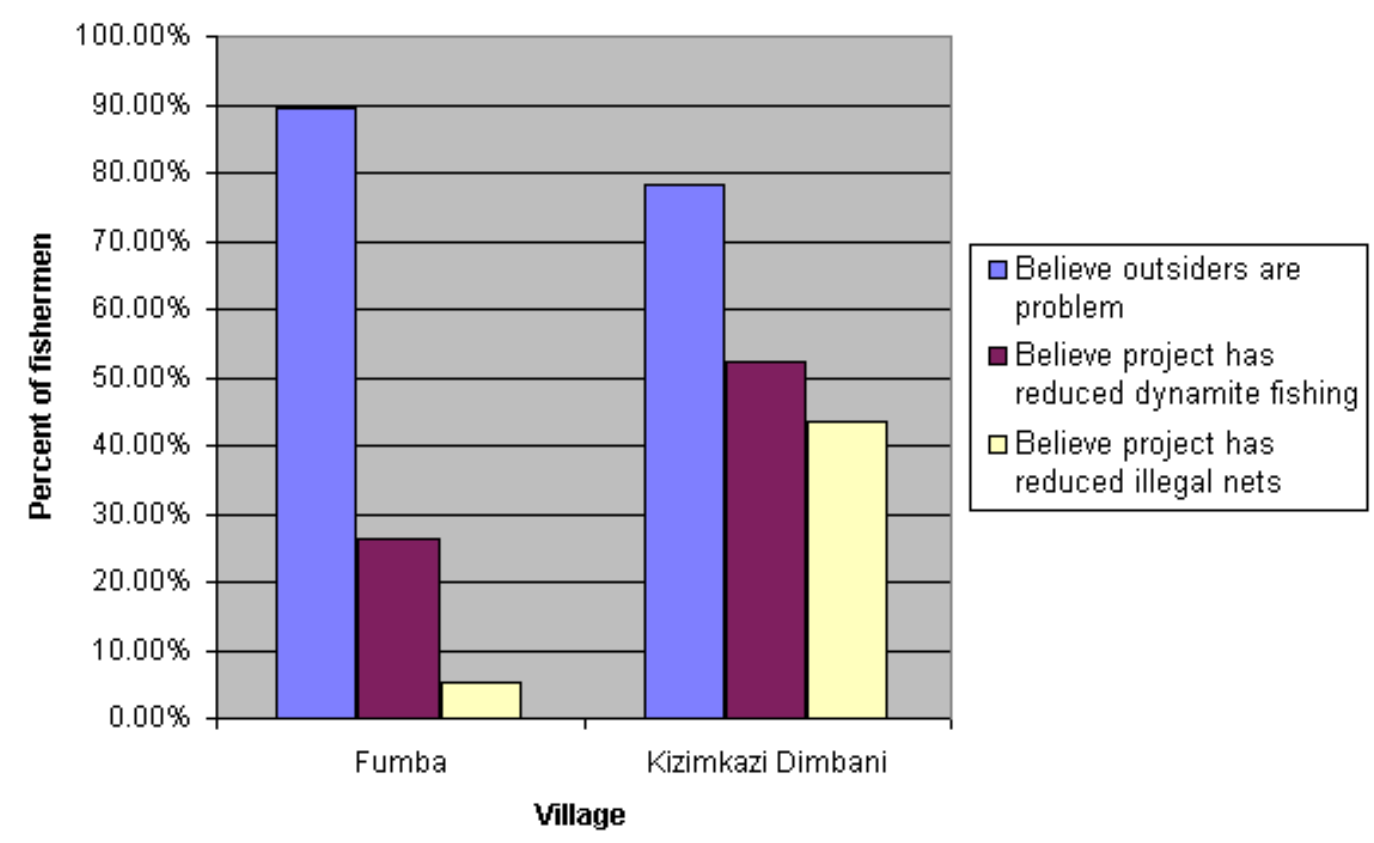

Fig. 4

Because of the ease and comfort of transportation to Kizimkazi Dimbani, as well as the noticeable presence of program resources (such as the patrol boats), the Menai program officers have been much more likely to bring donors and other visitors to this village to visit the program. This has resulted in Kizimkazi Dimbani becoming a kind of "showcase village" for the Menai Bay program. While this was probably not the initial intent, this situation has contributed to the further concentration of program attention and resources in Kizimkazi Dimbani. It has also opened up other opportunities to the village, such as increased international attention and the presence of tourism.

\section{Alternative income through tourism}

The tourist industry, which the Menai project has actively promoted as an ecologically friendly source of alternative income generation in the Menai Bay region, is already a notable source of 
employment in both Kizimkazi Dimbani and Fumba. The presence and potential of tourism is probably greater in these villages (with easy ocean access) than in most other villages in the project area. Fishermen in both villages work for outside companies taking tourists out to sea, and many fishermen in Kizimkazi Dimbani also lead dolphin tours in their own boats using personal resources and initiative. The Menai project actively promotes tourism in the Kizimkazi region, and opportunities for independent employment are greater in this area because its popularity and the condition of the road bring frequent casual day visits from tourists. The Menai Program has also tried to use tourism as a source of program revenue, attempting to tax tour operators at two dollars a head. This scheme met with considerable resistance from individual fishermen and tour operators alike, both in Kizimkazi Dimbani, where those working in tourism were worried that the fee would discourage visitors, and in Fumba where fishermen and tour operators alike believed that they were receiving few benefits from the project.

Tourism is a major factor contributing to the greater relative wealth of fishermen in Kizimkazi Dimbani compared with Fumba. The use of boats with outboard engines, a proxy indicator of the economic status of fishermen, is dramatically higher in Kizimkazi Dimbani than in Fumba (fig. 5). This greater use of outboard engines allows Kizimkazi fishermen to travel farther to fish, making them less reliant on their immediate area, and thus less threatened by destructive fishing in their region. Engine ownership also allows fishermen to independently take tourists out in their own boats, further increasing their potential to earn tourist income.

Fishermen's Use of Outboard Engines

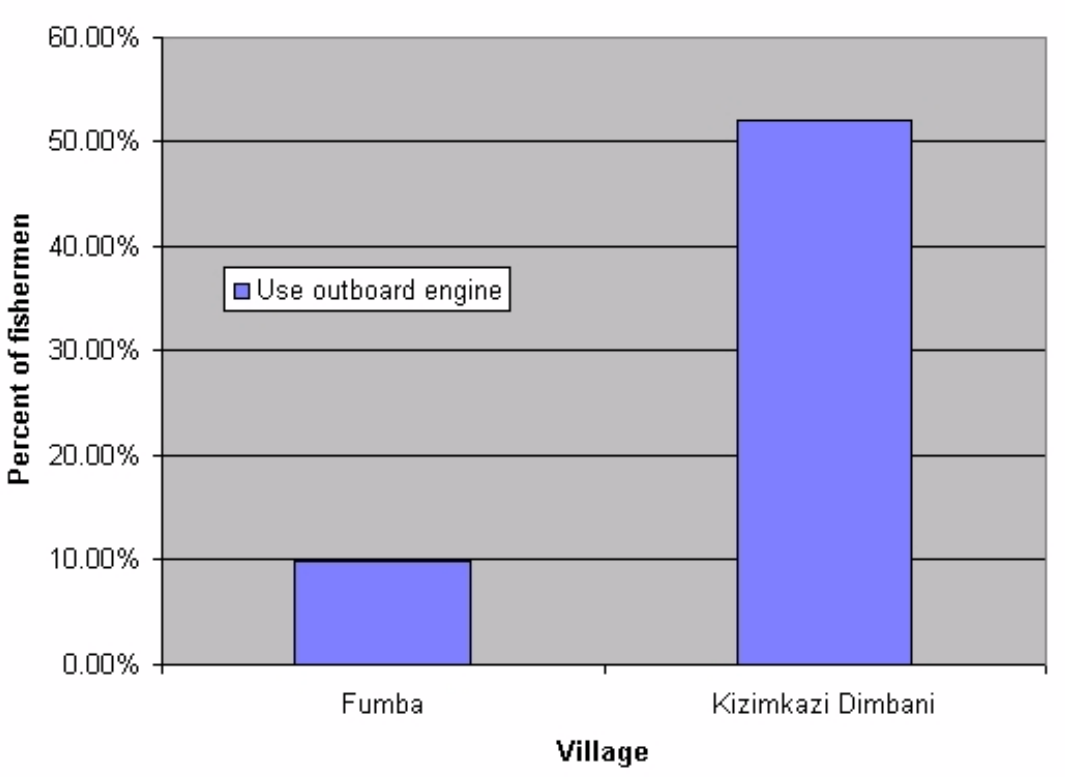

Fig. 5

Fishermen in Kizimkazi Dimbani see the presence of tourism as a strong benefit provided by the Menai program, bringing in supplemental income and employment opportunities for other people who might otherwise leave the village to find work in town. As one fishermen stated, "the village benefits because many youth get employment when indeed our own government says that there are no jobs. It isn't customary for many of our youth to move to town when they finish 
school because there is work here and they help each other. A person can earn two to three thousand shillings [here] that people in town can't get. Also, our village has become well known because many different visitors come here... and many make contributions.",2

Fumba fishermen see the relationship between the Menai project and tourism differently. When asked about the two-dollar contribution that the project was soliciting from tourist operations, many fishermen cited corruption within the project. One fishermen responded, "truthfully, this project has been given a lot of money by donors and they have not done one thing of meaning; they've used all of this money and they've done nothing... They say they do patrols, but they don't do this - they just take tourists out to make money... They say that this money will help the village, but this isn't true. If they get money they eat it themselves and it doesn't help anything here. Now many people in Fumba don't believe in Menai.” Another Fumba resident emphasized the village's disillusionment with the project: “The people of Menai aren't honest... after we've seen that there is no truth, indeed we don't even pay one dollar, because although the project appears to be doing things for the environment, still... destructive fishing occurs even though the project has boats to enforce the law. Therefore there is no need to pay to make their [the project officers'] stomachs fat - there is no meaning.”

The uneven distribution of program attention and resources goes far to explain the differences in fishermen's attitudes between the two different villages. However, other villages participating in the project also suffer from negligible program attention, but their reaction against the project has not been nearly as extreme as in Fumba (fig. 6). As the village located farthest from the patrol headquarters and closest to the mainland and to town, the threat of outsider illegal fishing may be greater in the Fumba area than in other parts of the Bay, potentially exacerbating villagelevel dissatisfaction. However, the significant degree of dissatisfaction with the Menai program found among Fumba residents may also be explained by other historical factors within the village itself.

Fishermen expressing dislike for the Menai project

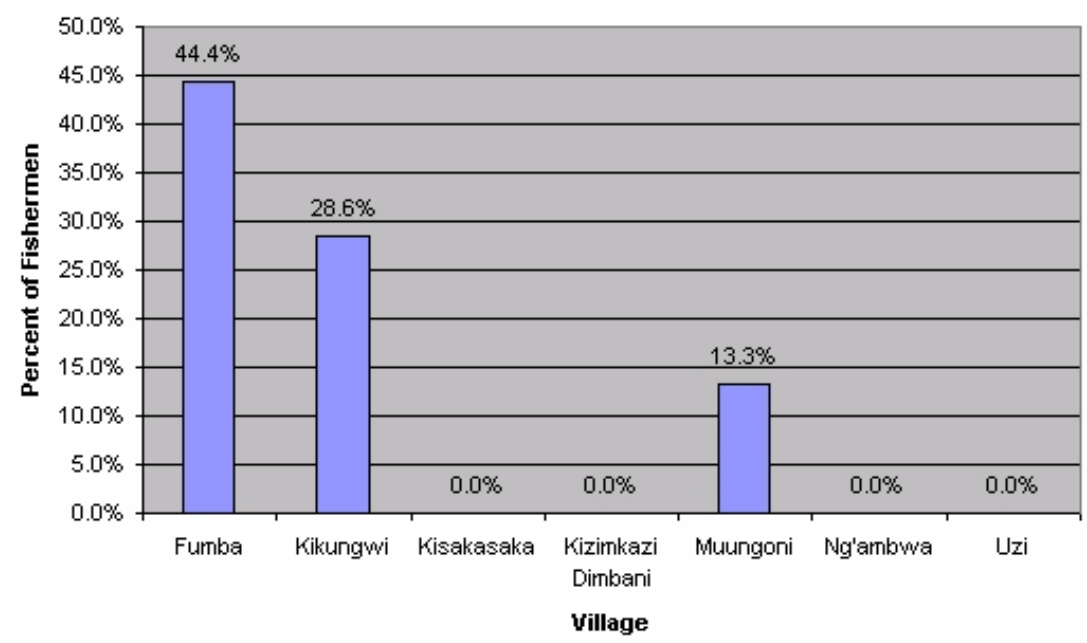

Fig. 6

${ }^{2}$ All quotes from fishermen are translated from the original Swahili by the author. 
Pre-existing village structures and conservation history

Fishermen in Fumba established their own village conservation committee in the early 1980s to fight the growing problem of the incursion of illegal fishing in their area. With the help of donor funding, they expanded this committee in 1992 to work with five other villages on the Fumba peninsula. This committee was not legally registered, but Fumba area villages contributed their own funds to purchase fuel and local fishermen volunteered to assist in patrolling in the area to prevent destructive fishing techniques. Fumba fishermen frequently cite with pride how they were "the first to protect the environment."

When the Menai project came to Fumba, the program officers asked the villagers to disassemble their local village conservation committee and create a new one under the auspices and structure of the Menai Bay program. The Fumba villagers willingly complied, expecting to receive increased support from the WWF-funded program. Unfortunately, the villagers state that they have since been abandoned by the project, the program officers never come to their village, and the patrol boat never reaches their area. One Fumba fisherman complained, "Menai, they've got problems - they don't send the boat. There used to be a committee here but it died a few years ago; it didn't work. People came from [the project] but they did nothing." Another complained: "Menai and WWF have done nothing for the committee - they've done zero. Nothing has come of it." Other fishermen express a sense of urgency: "They [the project] need to do real work because the coral is being broken, fish are ruined, destructive fishermen fish every day - it must be protected. Fishermen must not use destructive methods, and the project must do their work well. We don't want destructive fishing in Menai Bay.”

Much of the outrage in Fumba seems to stem from the feeling that the Menai project has undermined the efforts that the villagers initiated themselves. The program officers made promises to assist them, but instead focused their resources elsewhere. As one Fumba fishermen stated: "People in Fumba were the first to protect the environment. Here we were teachers for other areas, but the project removed us... now people from here have had their hearts broken they don't continue [to work to protect the environment].” Another Fumba resident present in the first conservation committee stated, "First I sat with the community regarding conservation; Menai came and then it was just the VCC, not the community anymore.”

Many fishermen also cite the increase in illegal nets in their area as a big problem, and they are frustrated that the program focuses its efforts and on the other side of the Bay. "Our strength has decreased because we have gotten nothing, it all goes to Kizimkazi...We've gotten no tools to protect against anything. People from Menai don't come often now... they've stopped coming completely, they only go to Kizimkazi.” Some villagers are outraged enough to state that the program officers are no longer welcome in Fumba. In early 2003, Fumba fishermen attempted to publicly voice their complaints about the project by publishing an article published in the local Zanzibar newspaper, "DIRA.” They complained about the increased presence of illegal fishing in their area, claiming "We call this a protected area, but this is a lie... This area is where we make our living. There is a word that says Marine Protected Area but this is an empty lie, it is just on paper” (DIRA 2003). 
The Menai project's failure to work with, and in fact to undermine, pre-existing village-based conservation structures goes far to explain the extreme resentment that many Fumba fishermen feel against the program. Kizimkazi Dimbani, on the other hand, had no formal village conservation committee before the Menai project began. The Menai program brought a formal structure and resources to the village to address issues such as the incursion of illegal fishermen in their area. It also helped to increase tourism in the village. Rather than undermining local structures in Kizimkazi Dimbani, the Menai project helped to build them, a factor which may help to explain the fishermen's high level of support for the program.

\section{Implications for community-based marine conservation programs}

Although the Menai Bay project's formally stated goals and models are the same for each village within the Menai Bay region, the outcomes and community-level responses vary tremendously within individual villages. The differences in responses from fishermen in Fumba and Kizimkazi Dimbani are an extreme example, but the responses from other villages involved in the Menai program also show similar variation across the Bay. This variation at the village-level is not unique to the Menai program, but is seen in the results from the majority of the case-study villages associated with marine protected area programs in Zanzibar, regardless of the structure of the program or the type of sponsoring organization. This within-program variation makes it very difficult to deem any single program to be a complete "success" or "failure," but requires that attention be paid to the nuanced differences within the program area itself.

It is difficult to predict which of the numerous potential contributing factors may account for program variations at the village level, and local factors vary significantly by case and by region. However, the Menai program provides some interesting lessons regarding important factors to consider in implementing community-based marine protected area programs. One of the more obvious and widely applicable considerations is the need to try to disperse program benefits across villages in a consistent and equitable way. While differences in geography and in local infrastructure may make this difficult, the resentment between villages that can result from unequal distribution of program attention and resources can be detrimental to the success and stability of the overall program. In the case of Kizimkazi Dimbani, the Menai program focused more resources in this easily accessible location, using it as a successful "showcase village" for donors, and indeed the level of program success and local support in Kizimkazi Dimbani is very high. However, this tactic did not go unnoticed by other participating villages, and many felt alienated or abandoned by the program. Focusing resources in an easily accessible location may also serve to further marginalize villages that are already politically and economically marginalized by poor access to transportation, communications, and infrastructure.

Additionally, it is important to pay particular attention to differences in local situations and history. Community-based conservation programs can be important tools for building local community structures to address conservation problems and for gaining community support. However, these programs must also take into account the previously existing societal structures within each village and attempt to work with these structures of civil society, rather than undermine them. While a village's previously existing organizations and techniques for addressing conservation issues may not necessarily fit neatly with the conservation model of a wider program, it is important to try to work with these local structures, which have a strong local base of support, rather than dismantle them in the hopes of creating a more even and 
generic program structure across villages. In the case of Fumba, the dismantling of the local conservation committee in favor of the Menai program's VCC model not only alienated local fishermen from the program, it also left the village without any effective village-based structures to address the growing problem of illegal fishing in the area.

\section{Externally-sponsored conservation and the state}

A wider issue in community-based marine conservation in Zanzibar, and one that is perhaps more difficult to address, is the structural relationship between the government and the external institutions implementing marine conservation on the island. Although the government is a key collaborator at the ground level in terms of program implementation, the state does not generally play largely in the funding or formulation phase of the programs. The shortage of internal resources in the Zanzibari government requires that it work with external institutions to fund its conservation programs. However, the result can be that the government may not feel ownership of, or investment in, projects. When program funding is derived largely from external sources, it places the program sponsors, whether they are NGOs or private sector operators, in the position of a fatted calf that can be seen as a potential source of financial support for government priorities which may not fall in line with the program's conservation agenda. Government officials may cooperate with the program only as a means of gaining access to outside funding, rather than because they support or believe in the program's aims and goals.

Additionally, if the government does not see itself as directly invested in a project, then government officials and employees may potentially be more likely to try to skim resources from the program (at the expense of overall program goals) rather than to actively support it. A number of fishermen, and even some program employees, claimed that corruption was a problem in the Menai Bay program. If this is the case, then already inadequate program resources must be stretched even more thinly across the project's 19 villages. This perception of corruption also detracts from the program's relationship with individual villages, undermining community trust and cooperation.

Another challenge to the Menai program is that it lacks adequate support within the Zanizbari state's legal structure. Although the incidences of illegal fishermen being brought to court increased dramatically once the patrol system was established by the Menai program, very few of these fishermen have been substantially fined or punished, providing very little disincentive for the use of illegal fishing nets in the area. This might not be the case if the Zanzibari state felt ownership of the Menai program, potentially prompting a more active level of support and collaboration across the different sectors of the islands' government.

Since this study was conducted in 2002, some changes have taken place within the structure of the program. With the signing of a peace accord in late 2001 promising electoral reform between the Zanzibar's two major political parties, outside donor funding has slowly begun trickling back to the islands, leaving the state slightly less desperate for resources. Additionally, WWF expressed dissatisfaction with program funding and operations, and pushed for major structural changes on the threat of withdrawing their support entirely. While WWF continues to support the Menai program, the Department of Fisheries of the Zanzibar government is now contributing substantially to supporting the project through the secundment of local paid staff. The project also plans to build additional program offices in the Western and Central districts of 
Menai Bay (including one in Fumba) to attempt to more evenly distribute program and patrolling resources throughout the program area. Whether these structural changes will have a significant impact at the village level remains to be seen.

The Menai program provides an excellent example of the extremely complicated factors that are involved in implementing community-based conservation programs. The wide variation in village-level outcomes, both for and against the program, illustrates the need for increased attention to the nuances and details at the local level, as well as to the program's institutional and contextual setting. Applying a single model of conservation and community involvement across multiple villages, even villages located in a similar region and setting, is bound to result in very different results once that model hits local cultural, historical, and political realities. Although these different results are not entirely predictable, it is important to take local differences into account to try to minimize negative outcomes that might undermine long-term program success. Program techniques and policies must be adaptive to pre-existing local structures and to unpredicted individual situations that may arise. It is certainly a daunting task for an international conservation NGO (or any organization) to create a community-based marine conservation program that is sensitive to local contextual differences, has an adaptive management style which can respond to unexpected needs, and is integrated into both local-level and state-level structures. However, this kind of structure is what is necessary if communitybased conservation programs are to be effective and sustainable in the long term. 


\section{References}

AWF. 2004. The African Wildlife Foundation: Over 40 Years of History. http://www.awf.org/about/history.php.

Bigg, Matt. 1996. Donors block aid to Zanzibar, slam rights abuses. Reuters. Dar Es Salaam, May 7.

Brandon, K. E. \& Wells, M. 1992. People and parks : linking protected area management with local communities. Washington, D.C. : World Bank, World Wildlife Fund, USAID.

Brosius, J. P, Tsing, A. L. \& Zerner, C. 1998. Representing Communities: Histories and Politics of Community-Based Natural Resource Management. Society and Natural Resources,11, 157168.

DIRA. 2003. Fumba Yetu Inavamiwa. Wanakijiji wa Fumba, Zanzibar. March 10.

Dudley, Nigel and Stolton, Sue. 2003. Conserving Nature, Partnering with People: WWF's Global Work on Protected Area Networks. WWF - World Wide Fund for Nature. Gland, Switzerland.

Gibbon, P. 1995. Liberalized development in Tanzania: studies on accumulation processes and local institutions. Uppsala, Sweden: Nordiska Afrikainstitutet.

Gibson, C. C. \& S. A. Marks. 1995. Transforming Rural Hunters into Conservationists: An Assessment of Community-based Wildlife Management Programs in Africa. World Development, 23 (6), 941-57.

Government of Zanzibar. 1997. The Environmental Management for Sustainable Development ACT, 1996. Legal Supplement (Part 1) to the Zanzibar Government Gazette. Vol. CVI No. 5743 of $31^{\text {st }}$ May, 1997.

Human Rights Watch. 2002. The bullets were raining: The January 2001 Attack on Peaceful Demonstrators in Zanzibar. Human Rights Watch Report. Vol. 14, No. 3.

Kangwana, Kadzo and Mako, Raphael Ole. 1998. The Impact of Community Conservation Initiatives Around Tarangire National Park (1992-1997). Community Conservation Research in Africa: Principles and Comparative Practice Working Paper Series, No. 9. Institute for Development Policy and Management. Manchester, UK.

Leader-Williams, N., Kayera, J.A., \& Overton, G.L.. 1996. Community-based Conservation in Tanzania. Occasional paper of the IUCN Species Survival Commission. No. 15.

Levine, Arielle. 2002. Convergence or Convenience? International Development NGOs and Conservation Assistance in Tanzania. World Development. 30(6):1043-1055. 
Levine, Arielle. forthcoming 2004. Staying Afloat: Managing Marine Protected Areas in Zanzibar. Journal of International Wildlife Law and Policy.

Menai Bay Conservation Project. 2000. Utaratibu Maalum wa Matumizi ya Maliasili (MBCA General Management Plan)

Murphree, M. W. 1993. Communities as resource management institutions. Sustainable Agriculture Programme, International Institute for Environment and Development. Gatekeeper series, No. 36. London, U.K.

Neumann, R. P. (1998). Imposing Wilderness: struggles over livelihood and nature preservation in Africa. Berkeley. University of California Press.

Newmark, W. D., \& Hough, J. L. 2000. Conserving Wildlife in Africa: Integrated Conservation and Development Projects and Beyond. BioScience, 50, (7), 585.

Ngaga, Yonika M; Sharif, Mohamed H.; Makoloweka, Solomon. 1999. Support for communitybased conservation and sustainable use of natural resources in Menai Bay, Zanzibar: Mid-Term Evaluation Final Report. Menai Bay Conservation Area (MBCA) WWF-Tanzania Programme Office.

Spalding, Mark; Ravilious, Corinna; and Green, Edmund. 2001. World atlas of coral reefs. University of California Press, Berkeley. 